\title{
Occupational Health Hazards Associated with Continuous Exposure to Quarry Activities among Quarry Workers in Ebonyi State, South East Geopolitical Zone, Nigeria
}

\author{
Aloh E. Henry ${ }^{1,2}$, Aloh O. Getrude ${ }^{3}$, Otuu F. Chibuisi ${ }^{4,6}$, Elvis N. Shu ${ }^{5,6}$, Maduka \\ C. Ignatius ${ }^{6,10}$, Inya-Agha I. Stella ${ }^{7}$, Nwando C. Obi-Ezeani ${ }^{8}$, Tilako B. Halilu ${ }^{9}$, \\ Okechukwu C. Cyril ${ }^{11}$ \\ ${ }^{I}$ Department of Health Administration and Management, Faculty of Health Sciences, College of Medicine, \\ University of Nigeria Nsukka, Enugu Campus, Enugu State, Nigeria. \\ ${ }^{2}$ Department of Health Service, Federal University Ndufu-Alike Ikwo, Ebonyi State, Nigeria. \\ ${ }^{3}$ Department of Geography and Metrology, Faculty of Environmental Sciences, Enugu State University of \\ Science and Technology, Enugu State, Nigeria. \\ ${ }^{4}$ Department of Pharamaceutics, Faculty of Pharmaceutical Sciences, University of Nigeria, Nsukka, Enugu \\ State, Nigeria \\ ${ }^{5}$ Department of Pharmacology and Therapeutics, College of Medicine, University of Nigeria, Enugu Campus, \\ Enugu State, Nigeria. \\ ${ }^{6}$ Molecular and Environmental Toxicology Research Group, University of Nigeria, Nsukka, Enugu State, \\ Nigeria. \\ ${ }^{7}$ Department of Pharmacognosy and Environmental Medicine, University of Nigeria, Nsukka, Enugu State, \\ Nigeria. \\ ${ }^{8}$ Department of Chemical Pathology, Chukwuemeka Odumegwu University, Awka, Anambra State, Nigeria \\ ${ }^{9}$ Department of Medical Laboratory Sciences, Faculty of Health Sciences,University of Nigeria, Enugu Campus, \\ Enugu State, Nigeria. \\ ${ }^{10}$ Department of Chemical Pathology, University of Nigeria Teaching Hospital, Ituku Ozalla, Enugu State, \\ Nigeria \\ ${ }^{11}$ GreenAfriqueProject, Plot 46, Gana Street, Maitama, Abuja, Nigeria.
}

\begin{abstract}
Quarry industry is among the many extractive industries implicated in the etiology of a myriad of occupational health hazards. This study brought forth the case of health hazards among quarry workers in Ebonyi State, southeast geopolitical zone of Nigeria. Simple randomized sampling technique was adopted in selection of 49 sites among 130 quarry sites, within Ebonyi state. A total of 392 participants were selected from the quarry workers and the same number of participants from non-quarry workers living within the same geographical location was selected as control. The test population was grouped into 3 categories according to the duration of exposure. Hazard assessment was carried out on the basis of clinical history, physical examination and assessment of lung function using Forced Expiratory Volume in one second (FEVI) as measured with a Peak-flow meter. Results show that $38.8 \%$ had mild cough, $6.6 \%$ severe persistent cough and 4.1\% heamoptysis. $48.2 \%$ had FEVI less than that of the control population. The average FEVI of the studied population was $306.9 \mathrm{ml}$ and that of control group was $319.4 \mathrm{ml}$, showing a difference of $12.5 \mathrm{ml}$. When this was tested at $95 \%$ confidence level $(t=10.59 ; C . V .=1.96 ; P \unlhd 0.05)$ there was significant difference between the lung function (FEVI) of the study population and that of the control. Pulmonary function loss increased with years of exposure. Workers of 5-10 years of exposure showed a loss of about 39.5ml FEVI and those with more than 10 years exposure showed a loss of $106.4 \mathrm{ml} \mathrm{FEVI.} \mathrm{There} \mathrm{was} \mathrm{no} \mathrm{significant} \mathrm{difference} \mathrm{in} \mathrm{the} \mathrm{pulmonary} \mathrm{function}$ of workers with less than 5years exposure and that of the control population. Occupational health hazards were both time and job-specifics dependent. There is a need for public enlightenment to all stakeholders (quarry workers, quarry industry owners, State/Federal Government and International Organizations) to put appropriate preventive measures in place.
\end{abstract}

Keywords: Forced expiratory volume, Occupational health hazards, Hazard assessment, Pneumonocicosis, Silicosis, Respiratory diseases 


\section{Introduction}

Quarry is one of the many extractive industries playing important role in the economies of many countries including Nigeria, creating employment, sustaining livelihoods and providing national income. Many countries have taken to quarrying to diversify their economic bases, and in Africa, quarrying activities are intensified as a main resource.

Rock quarrying and stone crushing is a global phenomenon, and has been the cause of concern everywhere in the world, including the advanced countries. Quarrying activity is a necessity that provides much of the materials used in traditional hard flooring, such as granite, limestone, marble, sandstone, slate and even clay to make ceramic tiles. However, like many other anthropogenic factors, quarrying activity causes significant impact on the environment (Okafor, 2006; Omosanya and Ajibade, 2011). In particular, it is often necessary to blast rocks with explosives in order to extract material for processing but this method of extraction gives rise to noise pollution, air pollution, damage to biodiversity and habitat destruction. Dust from quarry sites is a major source of air pollution, although the severity will depend on factors like the local microclimatic conditions, the concentration of dust particles in the ambient air, the size of the dust particles and their chemistry. For example, limestone quarries produce highly alkaline and reactive dusts, whereas coal mines produce acidic dust. The air pollution is not only a nuisance (in terms of deposition on surfaces) and possible effects on health, but dust can also have physical effects on the surrounding plants, such as blocking and damaging their internal structures and abrasion of leaves and cuticles, as well as chemical effects which may affect long-term survival (Guach, 2001).

Quarrying products are increasingly demanded for industrial, domestic, agricultural and other purposes so as to satisfy the needs of the rapidly growing population. Quarrying operations generally involve removal of over burden, drilling, blasting and crushing of rock materials. The various impacts produced by these operations are both size and location dependent. Manifestations of specific impacts are on the air, water, soil, earth surface, floral and fauna, and human beings (Areola, 1991; Enger and Smith, 2002). Apart from land degradation, other negative impacts of quarrying include swamp creation, deterioration of ground water, erosion of soil, noise and percussions from rock blasting, generation of dust, smoke and fumes; production of noxious gases and ground vibration. Suspended particulate matter is quite significant among all pollutants originating from quarrying operations (United State Environmental Protection Agency, USEPA, 2008).

Solid materials in the form of smoke, dust and also vapour generated during quarrying operations are usually suspended over a long period in the air. Moreover, particulate matters in the air are capable of being transported from the point of generation to areas far removed (United Nation Environmental Protection, UNEP, 1991). Once particles of varying chemical compositions are inhaled, they lodge in human lungs; thereby causing lung damages and respiratory problems (Last, 1998). According to Deborah (1996) and National Industrial Sand Association (1997), dusts generated from granite quarrying contain 71 percent silica. Inhaling such dust results in silicosis which is capable of disabling an exposed person and subsequently, leads to death. Apart from silicosis, sandblasters, miners and quarry workers are also at the risk of suffering from pneumoconiosis ().

Suspended particulate matter may be affecting more people globally than any other pollutant on a continuous basis (Richard, et al., 2002). Going by epidemiological studies, a dose-response relationship between exposure to $\mathrm{PM}_{10}$ and respiratory morbidity and mortality are established (Dockery and Pope, 1994; Pope, et al., 1995; Qamar, et al; 2001). Even at relatively low concentration (not exceeding standard guideline of $150 \mu \mathrm{g} / \mathrm{m}^{3}$ for 24 hours), inhalable particulate matters $\left(\mathrm{PM}_{10}\right)$ have adverse effects on human health.

Indeed, an increase of $50 \mathrm{mg} / \mathrm{m}^{3}$ in particulate levels is shown to induce increase death rate from 2 to 8 percent in several countries (Bart, 1993). Supporting this particulate level and health relationship, WHO (1994) indicated that daily mortality rates would increase by 20 percent with an increase of particulate level to $200 \mathrm{mg} / \mathrm{m}^{3}$. A report by the Environmental Working Group in California showed that respiratory illnesses caused by particulate matter are responsible for more than 10,000 deaths and 16,000 hospital admissions. The health care cost of these illnesses was put at $\$ 132$ million, in addition to millions of missed work days and school absences each year (Deborah, 1996; Douglas, 1996; USEPA, 1996). The circumstances surrounding most developing countries, Nigeria inclusive, is more pathetic in view of the utter disregard of pollution limits by most industries, low knowledge of environmental laws, exploitation of the mining community inhabitants, intimidation of the multi-national quarrying companies on the host communities, and the general poor living standard which affect people's nutrition status. In most African countries, the risks faced by those who are occupationally exposed are poorly researched.

In Ebonyi State, the major source of internally generated revenue for most Local Governments is the quarry business. This has led to the rapid increase in quarry activities, quarry sites, and increased environmental pollution in its rural communities. Owing to the abundance of sedimentary rock in the state, over 130 small and medium scale quarrying industries are currently operating in the state, employing about 3000 or more workers. With the increased demand for ceramic and building materials as well as extensive use of granite in construction industries, quarry activities have intensified with tempo and zeal hitherto unknown among most rural 
communities in Ebonyi state. This has affected the environment of the quarry areas negatively, as heaps of granites are scattered everywhere, exposing not only the quarry workers, but also the inhabitants of rural communities to heavy metals, amorphous particles and dust.

\section{Study Area}

\section{Methodology}

Ebonyi State of Nigeria occupies a landmass of approximately $5,935 \mathrm{~km}^{2}$, and lies on approximately latitude $7^{0} 30^{1} \mathrm{E}$ to $8^{0} 30^{0} \mathrm{E}$ and longitudes $5^{0} 40^{0} \mathrm{~N}$ to $6^{0} 45^{1} \mathrm{~N}$. The State is bounded to the East by Cross River State, to the West by Enugu State, to the South by Abia State and to the North by Benue State of Nigeria (Ebonyi State Ministry of Information, 1999). The type of quarrying industries present in Ebonyi State ranges from manual/individual stone quarrying to small and medium scale quarry industries that use heavy machinery for stone crushing. These industries constitute the major supplier of granite/stone chippings in the southern part of Nigeria.

\section{Ethical and Environmental Consideration}

The protocol for the study was reviewed by the Ethics Review Committee of the Ebonyi State Ministry of Health, Abakaliki. Peaceful community entry was achieved by seeking the permission of the quarry owners through an official application. Thereafter, the voluntary, first person Informed Consent of the workers involved in the study was obtained. The nurses and the physicians explained to each participant the study aim and objectives, methods, the nature of their involvement and the length of time of involvement, discomforts or risks, benefits, usefulness of the study, and plans for the use of the study findings. The informed consent form was read to the participants in the language of the workers (Igbo language).

\section{Sample size}

This study was carried out on 392 Quarry workers who were employed in small and medium scale quarry industries in Ebonyi State. The workers comprised largely of women between the ages of 16yrs and $60 \mathrm{yrs}$ plus fewer numbers of men between the ages of 20yrs and 60yrs. Few truck drivers who transport this crushed stone to various destinations were also included. The sampling size was calculated according to the formula for calculation of minimum sample size:

$$
\begin{aligned}
& \eta=\frac{z^{2} p q \text { (Akpala, 1994) }}{d^{2}} \\
& \eta=\frac{(1.96)^{2} \times 0.09 \times 0.91}{(0.05)^{2}}
\end{aligned}
$$

Where $\eta=$ Sample Size, $\mathbf{z}=1.96 ; p=0.09$ and $q=0.91 ;$ Sample error $=5 \% \boldsymbol{\eta}=\mathbf{1 2 5 . 8 6}$

Thus, expected minimum sample size, $\quad \eta=126$

A control population of 392 healthy people was selected, matched for age and sex, from the same area.

\section{Study design}

The study design was cross-sectional and assessed the health hazard confronting quarry workers in Ebonyi State with special attention to respiratory functions and lung diseases. Simple randomized sampling technique was adopted in selection of 49 sites among 130 quarry sites, within Ebonyi state. A total of 392 participants were selected from the quarry workers and the same number of participants was selected from nonquarry workers living within the same geographical location as control. The test population was grouped into 3 categories A, B, C according to the duration of exposure: (A) Less than 5 years exposure, (B) 5-10 years exposure, (C) More than 10 years exposure. Five types of assessment were carried out for the respective categories of workers: well structured questionnaire, clinical examination, and urinalysis were carried out for the three groups, while spirometry with peak flow meter was used to monitor FAV1 for categories A and B. Chest $\mathrm{X}$-ray was only used for category $\mathrm{C}$.

The questionnaire captured background variables (bio-data) and questions that were aimed at providing answers to the objective of the study. Clinical examination involved two physicians in the company of four nurses and two ward orderlies conducting a comprehensive clinical examination of each quarry worker, including chest auscultation. Spirometry with peak flow metre was used to measure FEV1 to assess pulmonary function. Urinalysis was carried out using combi-9 to determine presence of proteinuria and haematuria. Chest $\mathrm{X}$-rays were read by a radiologist.

\section{Data Analysis}

The questionnaire was analyzed using Epi-info analysis software version 6. The result of the assessment including spirometry (i.e. FEV1) and urinalysis were matched to the number of years of exposure. The radiological examination was limited to category $\mathrm{C}$ because the induction period between initial silica 
exposure and development of radiographically detectable nodular silicosis is usually $>10$ years. Shorter induction periods are associated with heavy exposures and acute silicosis may manifest within 6 months to 2 years following such massive exposure to silica dust (Surrat et al., 1977). The demographic data and the result of the clinical assessment were analyzed using Epi-info. Data obtained were tabulated and Mean FEVI calculated for various groups. The mean FEVI of the study population was compared with that of the control group using student t-test at $95 \%$ confidence interval.

\section{Results}

The results of the study are presented in tables 1-14. The demographic feature of the study is presented in tables 1 to 4 . The mean age of the quarry workers was 40.3 years, with the female workers predominating the working population in the ratio, 6.1. The working population was composed of $238(60.7 \%)$ employees, and 154 (39.3\%) of self-employed artisanal quarry operators. Among the quarry workers, majority, 300 (76.5\%) had worked for a period less than 5 years, $68(17.4 \%)$ had worked for 5-10 years, and $24(6.1 \%)$ had worked for more than 10 years. Most of the workers, 234 (59.7\%) were unskilled, and therefore engaged in collection of stones for the crushing machines, and loading of trucks. The population of the workers engaged in machine operation was, $18(4.6 \%)$ and those engaged in manual crushing was $12(3.1 \%$.) The awareness of the workers on the need to use protective devices such as respirators, nose and mouth masks was zero. This is presented in table5. Quarry owners made no provision for such devices. Observation of basic hygiene was noted. Some workers, $54(13.8 \%)$ bathed before leaving the worksite for home, changed into clean clothes, $162(41.3 \%)$ before going home, washed their hands,338 (86.2\%) before taking their meals and/or before snuffing or smoking. Only $2(0.5 \%)$ of the workers received one form of training or the other. Hazard assessment presented in table 6 revealed that dust inhalation was predominant, 320 (81.6\%) followed by physical injury, $224(57.1 \%)$, and noise pollution, $220(56.1 \%)$, while excessive heat was the least hazard, $24(6.1 \%)$ among the workers.

Clinical examination of the workers presented in table 7 revealed that minor fatigue, 224 (57.1\%), chest pain, $220(56.1 \%)$, fever, $192(50.0 \%)$, were common complaints, followed by body pains, $168(42.9 \%)$, occasional cough, $152(38.8 \%)$, numbness of the extremities, 132 (33.7\%), injury at workplace, $128(32.7 \%)$, weakness, $111(28.8 \%)$, weight loss, $102(26.0 \%)$, mild breathlessness on exertion, $62(15.8 \%)$, persistent chest pain, $56(14.3 \%)$, night sweat, 50 (12.8\%), impaired hearing, 48 (12.2\%), persistent cough, 26 (6.6\%), abnormal chest pain, $22(5.6 \%)$, decreased air entry into the lungs, 20 (5.1\%), haemoptosis, $16(4.1 \%)$, severe fatigue, 12 (3.1\%), loss of appetite, $10(2.6 \%)$, eye, 4 itching $(1.0 \%)$, prolonged or severe breathlessness on exertion, 2 $(0.5 \%)$ and skin rashes, $2(0.5 \%)$, among the quarry workers. Prolonged/severe breathlessness on exertion and skin rashes were the least of the clinical findings.

An assessment of the lung function of the quarry workers presented in tables 8 to 13 was carried out using spirometer to measure Forced Expiratory Volume within first 1 second (FEV1). The results of the test and control participants are shown in tables 8and9. A larger proportion, $15(62.5 \%)$ of workers with more than 10 years exposure exhibited low FEV1 in the range of 201-300 ml. For the same range of FEV1 only, 111 (37\%) of workers with less than 5 years exposure were found to exhibit pulmonary function as low as that. On the other hand, as much as, 144 (48\%) of workers with less than 5 years exposure showed FEV1 of 301-400ml, while only, 20 (29.4\%) of 5-10 years exposed workers were able to achieve FEV1 of that range. Thus, the number of years of exposure was inversely proportional to the FEV1 of the workers. Workers with more than 10 years exposure had FEV1 of not more than $300 \mathrm{ml}$, due to degree of respiratory function impairment.

The result of urinalysis presented in table 14 showed that 60 workers $(15.3 \%)$ had a trace of protein in their urine, while 12 workers $(3.1 \%)$ had haematuria (blood in the urine).The rest of the workers, $320(81.6 \%)$, showed normal urinalysis value.

\section{Discussion}

A cross-sectional study of 392 quarry workers in 49 quarry sites was carried out to assess occupationalhealth hazards among quarry workers in Ebonyi State using clinical history, physical examination, assessment of pulmonary function by spirometry (FEV1), urinalysis and chest x-ray. The mean age of the quarry workers under study was 40.3 years with $19.4 \%$ of the workers within the age range of 10-19 years. This has sociocultural implications realizing that this is the school age bracket. The majority (49\%) of the workers were within age range of 40-59 years. The sex ratio of the study population was 6:1 (female, male) showing that the majority of the work forces were women. This brings to focus the problem of labour distribution among the genders in quarry industry. This might be due to the fact that women in our society often work in positions with lower pay, less power and frequently little control over their jobs or work functions. It is therefore important to integrate gender concerns in the policy measure of what may constitute an occupational safety for the workers. Quarry activities have documented evidence of immunologic, haematologic and hormonal alterations (Ghio et al., 2003), which may have negative implications on reproductive physiology, as some of the wastes associated with quarrying have teratogenic, carcinogenic, and mutagenic properties (Alakija et al., 1990).The job 
specification of the study population indicated that most of the workers were involved in the loading section. Thus, their jobs entailed manual collection of crushed stones away from crushing machine. This could explain why physical injury and general body pain were some of the most predominant symptoms among workers. The effect of load on the cranial anatomy and entire body kinetics depends on the weight and composition of the materials being carried, and the distance from the point of collection to the point of discharge. The observed numbness of the extremities could be attributed to this job-specific. Hazard evaluations and field studies carried out in USA showed that quartz concentration varied significantly by plant and job (Sanderson et al., 2000). In this study it was observed that the groups of workers in loading section were exposed to very high concentration of granite dust, exacerbating the possibilities of particulate matter and dust inhalation with its attendant pulmonary diseases. Though the study was designed to do Chest X-ray on all 24 workers who had been exposed for more than 10 years, only 3 workers turned up for the x-ray. The result of these $\mathrm{x}$-rays as reported by a radiologist was normal. Literature review of previous studies, showed that analysis of chest radiograph of exposed subjects using ILO international classification resulted in $15.8 \%$ abnormal films (Lee et al., 2001). According to Symanski et al, a serial chest x-ray of acceptable quality taking over a period of 5-10years is necessary (Symanski, 1981). The emphasis of the study was therefore focused on the first four assessments.

Assessment of hazard awareness among the workers showed the level of ignorance of the quarry workers and their employers on the health hazards associated with crude and unprotected quarry activities. Little protective measures were observed by the workers in line with other studies such as the case of Edo State of Nigeria by Isah et al (1997). The clinical history of the study population yielded about 22 symptoms and signs that were listed and scored using frequency or percentage of workers reporting with each ailment. It was observed that the commonest symptoms were minor fatigue, occasional chest pain, fever and cough, which were indicative of various disease entities. This was not surprising since silica dust exposure is also associated with the following diseases (either alone or in association with silicosis): Silico-tuberculosis or tuberculosis (Partanen et al., 1995; Charalambous et al. 2001), lung cancer (Guenel et al., 1989; Steenlan et al., 2002), Idiopathic pulmonary fibrosis (Baumgrartner et al., 2000), Renal impairment and disease such as Weggner granullomatosis (Straif et al., 2000), Immunoglobin (Ig) A nephropathy, Scleroderma, and Rheumatoid arthritis (Turner and Cherry, 2000). It has been reported that silicosis is the most common and most frequently seen tuberculosis-complicated pneumoconiosis (Probl Tuberk, 2001). Thus the second important illness associated with crystalline silica is pulmonary tuberculosis. Some studies in India reported that up to $50 \%$ of patients with silicosis have pulmonary tuberculosis (Jindal, 2001). In our study, chest-related symptoms, occasional and persistent coughs, weight loss and night sweats were significantly observed. These symptoms are also associated with pulmonary tuberculosis. In 1997, the International Agency for Research on Cancer (IARC) upgraded its evaluation of crystalline silica to a human carcinogen (Cocco, 2001). The risk of lung cancer is associated with the year of and age at first exposure to silica, duration of exposure and latency (Ulm, 1999).

Symptoms of silicosis include dyspnea (breathlessness), cough (Soutar et al.,, 2000), weight loss, fatigue, night sweat and occasional fever (Laraqui et al., 2001). A study done here in Nigeria (in a village near Kano) using unselected group of 126 stone cutters revealed radiologic evidence of silicosis in $38.8 \%$ which is unexpectedly high (Gupta et al., 1999). The present study is in tandem with the above previous reports, indicating that the workers were exposed to pulmonary diseases.The mean FEVI of $306.9 \mathrm{ml}$ for the study population, as compared to $319.4 \mathrm{ml}$ for control population marched for age also suggested the existence of respiratory anomalies of occupational origin. This was supported by student $t$-test used to test the significance of this difference $(12.5 \mathrm{ml})$ in the mean FEVI for the study group and the control population at $95 \%$ confidence level at $\mathrm{P}<0.05$.FEVI for various years of exposure showed that workers with short duration of exposure had higher FEVI and that the FEV1 decreased with increased exposure period implicative of the time dependent effect of continuous exposure of quarry workers to occupational health hazards.

Analysis of the FEVI for workers that used snuff or/and smoked tobacco showed a mean FEVI of $290.2 \mathrm{ml}$. When compared with the mean FEV1 of the study population it showed that snuffing or smoking of tobacco also enhanced deterioration of lung function. This finding is similar to that of Gupta in India (Gupta et al., 1999). A similar study to the present one, done by Institute for Risk Assessment Science, Environmental and Occupational Health group in Netherlands showed a significant association between exposures to concrete dust and lung function loss (Meijer et al., 2001). This loss appeared most severe in the presence of disease (Baimanova and Akhmetzhanova, 2001), even though, its presence was still independent of silicosis (Ng and Chan, 1992). The highly exposed workers showed greater prevalence of chronic cough and phlegm and a mean reduction of 5\% in FEVI ( $\mathrm{Ng}$ et al., 1992). Past studies have shown that sand workers had FEVI that was significantly lower than that of healthy adults from the study area (Mathur et al., 1996). This could be because cumulative exposure to respirable dust was the most important risk factor, (with or without disease) for manifestation of respiratory symptoms and impaired lung function (Ulvestad et al., 2001).

On the contrary, in few studies on quarry employees, by other researchers, there was no association between respiratory symptoms or spirometric result and dust-exposure (Lemle et al., 1994). A study done in 
Japan by Baba et al on 121 dust workers whose chest x-rays were found to be "class 1" of the diagnostic criteria for pneumoconiosis indicated that all the pulmonary function variables showed no correlation with smoking and total years of dust exposure, rather aging was the most dominant factor for pulmonary dysfunction (Baba et al., 1983). Assessment of some parameters indicative of renal function in the study population showed that 60 persons $(15.3 \%)$ had a trace of protein in the urine, while 12 workers $(3.1 \%)$ have haematuria (blood in the urine). This gave a total of $18.4 \%$ with evidence of renal pathology. Impairment of renal function due to prolonged exposure to dust was reported by Lapiti et al many years ago (Rapiti et al., 1999).

\section{Conclusions}

The FEVI of quarry workers decreased with years of exposure, suggestive of a gradual loss of lung function as years of exposure to respirable dust increased. The findings in this study showed that there were evidences of decreased lung function and renal pathology and perhaps other diseases among quarry workers. However, it was not possible to confirm incidence of silicosis because of the small number of workers with 10 or more years of exposure to silica dust in the study. Nevertheless, small airways obstruction might still be present among silica-exposed workers in the absence of radiological evidence of silicosis (Chia et al., 1992).

\section{Recommendations}

We therefore recommend that appropriate mitigating measures be adopted to minimize the inherent occupational hazards associated with quarry workers. Such measures as the use of water hose to sprinkle water at the dusty area will minimize the volume of dust and particulate matter present in the ambient air of the quarry site. The use protective devices such as respirators, coverall, crash helmets, industrial hand gloves, will limit respiratory and dermal dust contamination of workers. Routine medical examination of the workers should be enforced on the employers of the quarry workers. Appropriate regulatory agencies such as Ebonyi State and Federal Ministries of environment, State and National Assemblies and necessary Trade Unions are advised to formulate stricter policies that will ensure firm observance of environmental laws.

\section{References}

[1]. Akpala C. O. Epidemiological Research: A practical approach for the medical and nursing sciences. Department of Management, Faculity of Business Administration, University of Nigeria, Enugu campus, Enugu. 1994;64

[2]. Alakija, W, Iyawa, V, Jankira, LM, Chiwuzie JC (1990) Ventilator function of workers at Okpella Cement Factory in Nigeria, West Africa J Med. 9(3) 187-192

[3]. Areola, O (1991); Ecology of Natural Resources in Nigeria; Avebury Academic Publishing Group, Aldershot, England; Pp 178196.

[4]. Articles in Russsian. Silicosis is the most common and most frequently tuberculosis-complicated pneumoconiosis with poor prognosis.,Probl Tuberk 2001;(6):22-3

[5]. Baba Y, Iwawo S, Kodama Y. A follow-up study on pulmonary functions of workers exposed to various forms of dust. Observation on the workers of pneumoconiosis in Kitakyushu JUOEH 1983 Dep1; 5(3): 351-8.

[6]. Baimanova AM, Akhmetzhanova BT. Flow volume curve evaluation of respiratory function in wolfram-molybdenum miners.,Med Tr Prom Ekol 2001;(3):16-9.

[7]. Bart, O. (1993). The Association of air Pollution and Mortality: Examining the case for inference; Archives of Environmental Health, Vol. 48, No. 5, P 336.

[8]. Baumgrartner KB, Samet JM, Coultas-DB, Stdley CA, Hunt WC, Colby TV. Occupational and environmeal risk factors for idiopathic pulmonary fibrosis: a multicenter case-control study. Collaborating centres., Am-J-Epidemiol. 2000 Aug 15; 152(4): 30715.

[9]. Charalambous S, Churchyard, GJ, Murray J, De Cock KM, Corbett EL. Persistent radiological changes following military tuberculosis in miners exposed to silica dust.,Intt J Tuberc Lung Dis 2001 Nov;5(11):1044-50.

[10]. Chia KS, Ng TP, Jeyaratnam J. small airways functions of silica-exposed workers.,Am J Ind Med 1992;22(2):155-62

[11]. Cocco P. Multifactorial aetiology of lung cancer among silica-exposed workers. Ann Acad Med Singapore 2001 Sep;30(5):468-74

[12]. Deborah, S. (1996). Breathtaking: premature Mortality due to Particulate air pollution in 239 America Cities. Natural Resources Defence Council, New York. Pp $14-15$.

[13]. Dockery, D., Pope, C. (1994); 'Acute respiratory effects of particulate air pollution'; Annual Review of Public Health; Vol.15, pp.107-132

[14]. Douglas, D. (1996); Health effects of Acid Aerosols on North America Children: Respiratory symptom; Environmental Health Perspectives, Vol. 104, No. 5 P 503.

[15]. Ebonyi State Ministry of Information. Welcome to Ebonyi State, the salt of the nation. 1999; 5.

[16]. Enger, E.D and Smith, B.F (2002); Environmental Science: A study of Interrelationship (8th edition) McGraw-Hill Higher Education, New York Pp372 -377

[17]. USEPA (2008); Region 4: Laboratory and Field operations - PM 2.5: Objectives and History. As available at en.wikipedia.org/wiki/particulate

[18]. Gauch, H.G (2001). Multivanate Analysis in Community Ecology Cambridge University Press, p. 85

[19]. Ghio AJ, Hall A, Basset MA, Cascio WE, Devlin RB. Exposure to concentrated ambient air particles alters haematological indices in humans. Inhal. Toxicol 2003 15. 1465-78

[20]. Guenel P, Hojberg G, Lynge E. Cancer incidence among Danish stone workers., Scand J Work Environ Health 1989 Aug;15(4):265-70

[21]. Gupta P. Chaswal M, Saxena S. Ventilatory functions in stone quarry workers of Rajasthan.Indian J Physiol 1999 Oct;43(4):496500 . 
[22]. Isah, E.C. Asuzu, M.C. and Okojie, O.H. Occupational Health Hazards in Manufacturing Industries in Nigeria, Journal of Community Medicine \& Primary Health Care 1997 Dec; vol 9:26-34.

[23]. Jindal SK, Aggarwal AN, Gupta D. Dust-induced interstitial lung disease in the tropics.Curr Opin Pulm Med 2001 Sep;7(5):272-7

[24]. Last, J.M; (1998); Public Health and Human Ecology; (2nd Edition) McGraw-Hill Medical Publishing Prentice-Hall Int; Edition Canada; Pp153-200.

[25]. Laraqui CH, Laraqui O, Rahhali A, Harourate K, Tripodi D, Mounassif M, Yazidi AA. Percentage or rate of symptoms.,Int J Tuberc Lung Dis 2001 Nov;5(11):1051-8

[26]. Lee HS, Phoon WH, Ng TP. Radiological progression and its predictive risk factors in silicosis, Occup Environ Med 2001, Jul;59(7):467-71

[27]. Lemle A, de Araujo AJ, Lapa e Silva JR, Lima Fd. Cardoso AP, Camara Wd, de Lucca W, Marchiori E, Carnevalli LC, Colucci AL. Respiratory symptoms and spirometric tests of quarry workers in Rio de Janeiro.Rev Assoc Med Bras 1994 Jan-Mar; 40(1): 2335

[28]. Mathur ML, Dixit AK, Lakshminarayana J. Correlates of peak expiratory flow rate: a study of sand stone quarry workers in desert.Indian J. Physiol Pharmacol 1996 Oct;40(4):340-4.

[29]. Meijer E, Kromhout H, Heederik D. Respiratory effects of exposure to low levels of concrete dust containing crystalline silica. Am J Ind Med 2001 Aug;40(2):133-40

[30]. $\mathrm{Ng} \mathrm{TP}$, Chan SL. Lung function in relation to silicosis and silica exposure in granite workers. Eur Respir J 1992 Sep;5(8):986-91

[31]. Ng TP, Phoon, WH, Lee HS, Ng YL, Tan KT. An epidemiological survey of respiratory morbidity among granite quarry workers in Singapore: chronic bronchitis and lung function impairment.,Ann Acad Med Singapore 1992 May;21(3):312-7.

[32]. Okafor FC, (2006); Rural Development and the Environmental Degradation versus Protection: In P.O. Sada and T.Odemerho (ed); Environmental Issues and Management in Nigeria Development; pp. 150-163.

[33]. Omosanya K.O.; Ajibade O.M. (2011); Environmental Impact of Quarrying on Otere Village, Odede, South Western Nigeria; Department of Earth Sciences, Ozean; Journal of Applied Sciences; 4(1): 76-81.

[34]. Partanen T, Jaakkola J, Tossavainen A. Silica, silicosis and cancer in Finland.,Scand J Work Environ health 1995;21 suppl 2:84-6

[35]. Pope, C., Bate, D.V. and Razienne, M.E. (1995). Health effects of Particulates in air pollutant: Time for re-assessment? Environmental Health perspective; 103: 472-475.

[36]. Qamar, R., Paul, N., Kirk, R.S., Prahlad, K.S. and James S. (2001); International Conference on Environmental and occupational Lung Diseases; Environmental Health Perspectives Vol. 109 No. 4; Pp 425-431

[37]. Rapiti E, Seperati A, Miceli M, Forastiere F, Di Lallo D, Cavariani F, Goldsmith DF, Perucci CA. End stage renal disease among ceremic workers. Occup Environ Med. 1999 Aug; 56(8): 559 - 561

[38]. Richard, T., Michael, J., Eugenia, E., Daniel, K., Kazuhiko, I. and George, D. (2002); Lung cancer, cardiovascular mortality and long-term exposure to fine particulate air pollution; Journal of American Medical Association; Vol. 287, No. 9.

[39]. Sanderson WT, Steenland K, Deddens JA. Historical respirable quartz exposures of industirla sand workers: 1946-1996, Am J Ind Med 2000 Oct;38(4):389-98.

[40]. Soutar CA, Robertson A, Miller BG, Searl A, Bignon J. Epidemiological evidence on the carcinogenicity of silica: factors in scientific judgment. Ann Occup Hyg 2000 Jan;44(1):3-14.

[41]. Steenlan K, Mannetje A, Boffetta P, Stayner L, Attfield M, Chen J, Dosemeci M, Deklerk N Hnizdo E, Koskela R, Checkoway H Cancer Causes Control 2002 Nov;12(9):773-84

[42]. Straif, K; Keil, U; Taeger, D; Holthenroch-D; Sun-y; Bungers-M; Weiland-SK, Exposure to nitrosamines, carbon black, asbestos, and talc and mortality from stomach, lung and laryngeal cancer in a cohort of rubber workers.,Am-J-Epidemiol.2000 Aug 15; 152(4): 297-306.

[43]. Surratt Pm, Winn Wc. Brody Ar, Bolton WK and Giles R.D Acute Silicosis in Tombstone blasters, Am Rev Respir Dis 1977: 115: 521-529.

[44]. Symanski H. Delayed onset sandstone pneumoconiosis: a case report, Am J Ind med 1981; 2(2):101.

[45]. Turner S, Cherry N. Rheumatoid arthritis in workers exposed to silica in the pottery industry. Occup Environ Med 2000 Jul; 57(7): 443-7

[46]. Ulm K, Waschulzik B, Ehnes H, Silica dust and lung cancer in the German stone, quarrying and ceramic industries: results of a case-control study. Thorax. 1999 Apr;54(4):347-51.

[47]. Ulvestad B, Bakke B, Eduard W, Kongerud J, Lund MB. Cumulative exposure to dust causes accelerated decline in lung function in tunnel workers.,Occup Environ Med 2001 Oct;58(10):663-9.

[48]. UNEP (1991); Urban air Pollution; In: Environment Library, No. 4, Nairobi: UNEP.

[49]. USEPA (1996); Review of National Ambient Air Quality standards for Particulate Matter: Policy Assessment of scientific and Technician information, Report No. EPA- 452/R-96-013 (USEPA, Washington D.C) Pp V-20 -V-24, V- 27, V-28 \& V-71.

\section{APPENDIX}

Table 1: Age Distribution Of Quarry Workers

\begin{tabular}{|l|l|l|}
\hline $\begin{array}{l}\text { Age } \\
\text { (years })\end{array}$ & Frequency (f) & Percent \\
\hline$\leq 9$ & 2 & 0.5 \\
\hline $10-19$ & 76 & 19.4 \\
\hline $20-29$ & 32 & 8.2 \\
\hline $30-39$ & 44 & 11.2 \\
\hline $40-49$ & 118 & 30.1 \\
\hline $50-59$ & 74 & 18.9 \\
\hline $60-69$ & 44 & 11.2 \\
\hline$>70$ & 2 & 0.5 \\
\hline Total & 392 & 100 \\
\hline
\end{tabular}

Table 2: Sex Ratio Of Quarry Workers

\begin{tabular}{|l|l|l|l|}
\hline Sex & Frequency & Percent & Ratio \\
\hline Male & 60 & 15.3 & 1 \\
\hline Female & 232 & 84.7 & 6 \\
\hline TOTAL & 392 & $100 \%$ & \\
\hline
\end{tabular}


Table 3: Years Of Exposure To Silica (Quarry Dust)

\begin{tabular}{|l|l|l|}
\hline Duration of Exposure in years & No of workers (freq) & Percent \\
\hline Less than 5 years & 300 & 76.5 \\
\hline 5-10 years & 68 & 17.4 \\
\hline More than 10 years & 24 & 6.1 \\
\hline TOTAL & 392 & $100 \%$ \\
\hline
\end{tabular}

Table 4: Types Of Duty Performed By The Workers (Job Discription):

\begin{tabular}{|l|l|l|}
\hline Job Specification & No of workers & Percent \\
\hline Stone Blastering & 6 & 1.5 \\
\hline Crushing Machine Operator & 18 & 4.6 \\
\hline Manual Crushing & 12 & 3.1 \\
\hline Collection of Stone from grinding machine & 234 & 59.7 \\
\hline Loading Section & 122 & 31.1 \\
\hline Total & 392 & $100 \%$ \\
\hline
\end{tabular}

Table 5: Level Of Awareness ( $\mathrm{N}=392)$

\begin{tabular}{|l|l|l|}
\hline Preventive Measures & $\begin{array}{l}\text { Level of Awareness (No. of workers } \\
\text { taking precautionary measures) }\end{array}$ & Percent \\
\hline Use of Respirator & 0 & 0 \\
\hline Use Nose/Mouth mask & 0 & 0 \\
\hline Bathing before leaving work site for home & 54 & 13.8 \\
\hline Change to clean clothes before going home & 162 & 41.3 \\
\hline $\begin{array}{l}\text { Wash hand before meal and/or before } \\
\text { snuffing or smoking }\end{array}$ & 338 & 86.2 \\
\hline Any form of training & 2 & 0.5 \\
\hline
\end{tabular}

Table 6: Common Hazard Experienced At Work Sites $(\mathrm{N}=392)$

\begin{tabular}{|l|l|l|}
\hline Occupational Hazard & Frequency & Percent of worker with the compliant \\
\hline Physical Injury & 224 & 57.1 \\
\hline Noise Pollution & 220 & 56.1 \\
\hline Dust Inhalation & 320 & 81.6 \\
\hline Excessive Heat & 24 & 6.1 \\
\hline
\end{tabular}

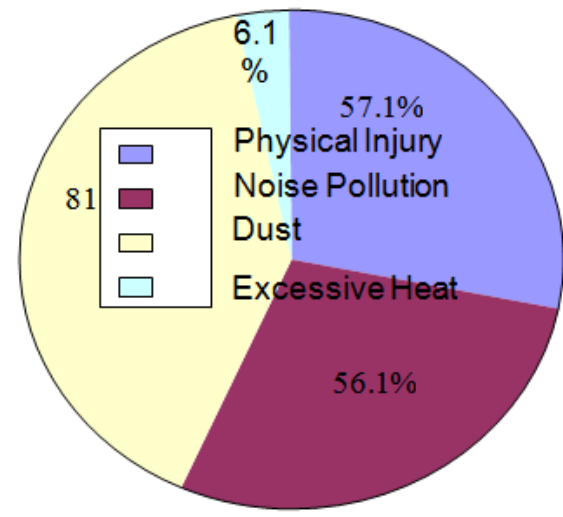

Fig. 1: Common Hazard Experienced At Work Sites

Table 7: Common Symptoms And Signs Among Quarry Workers ( $\mathrm{N}=392)$

\begin{tabular}{|l|l|l|}
\hline Symptoms/Sign & Frequency & Percentage of total population \\
\hline Body pains & 168 & 42.9 \\
\hline Fever & 192 & 50.0 \\
\hline Loss of appetite & 10 & 2.6 \\
\hline Weakness & 111 & 28.8 \\
\hline Occasioned cough & 152 & 38.8 \\
\hline Persistent cough & 26 & 6.6 \\
\hline Heamoptosis & 16 & 4.1 \\
\hline Mild breathlessness on exertion & 62 & 15.8 \\
\hline $\begin{array}{l}\text { Prolonged or severe breathlessness on } \\
\text { exertion (SOBE) }\end{array}$ & 2 & 0.5 \\
\hline Minor fatigue & 224 & \\
\hline Severe fatigue & 12 & 57.1 \\
\hline Weight loss & 102 & 3.1 \\
\hline Night sweat & 50 & 26.0 \\
\hline Occasional chest pain & 220 & 12.8 \\
\hline Persistent Chest Pain & 56 & 56.1 \\
\hline
\end{tabular}




\begin{tabular}{|l|l|l|}
\hline Numbness of the extremities & 132 & 33.7 \\
\hline Injury at workplace & 128 & 32.7 \\
\hline Impaired hearing & 48 & 12.2 \\
\hline Abnormal chest shape & 22 & 5.6 \\
\hline Decreased air entry into the lungs & 20 & 5.1 \\
\hline Eye itching & 4 & 1.0 \\
\hline Skin rashes & 2 & 0.5 \\
\hline
\end{tabular}

Table 8: Fevi Distribution For The 392 Quarry Workers And That Of Control Popution.

\begin{tabular}{|l|l|l|l|l|}
\hline \multirow{2}{*}{ FEVI (ML) } & \multicolumn{2}{|l|}{ Quarry Workers } & \multicolumn{2}{l|}{ Control population } \\
\cline { 2 - 5 } & $\begin{array}{l}\text { Frequency } \\
\text { (f) }\end{array}$ & Percentage & $\begin{array}{l}\text { Frequency } \\
\text { (f) }\end{array}$ & Percentage \\
\hline$\leq 200$ & 24 & 6.1 & 23 & 5.8 \\
\hline $201-300$ & 165 & 42.1 & 141 & 36.0 \\
\hline $301-400$ & 164 & 41.8 & 170 & 43.4 \\
\hline $401-500$ & 36 & 9.1 & 51 & 13.0 \\
\hline$>500$ & 3 & 0.7 & 7 & 1.8 \\
\hline Total & 392 & $100 \%$ & 392 & 100 \\
\hline
\end{tabular}

$(\mathbf{t}$ calculated $=10.59 ; \mathbf{t}$ critical value $=1.976 ; \mathrm{P}<0.05)=$ significant.

From this table the Mean FEVI for study population is $306.9 \mathrm{ml}$.

Table 9: Fevi And Years Of Exposures

\begin{tabular}{|l|l|l|l|}
\hline \multirow{2}{*}{ FEVI } & $\begin{array}{l}\text { Less than 5yrs of } \\
\text { exposure }\end{array}$ & $\begin{array}{l}\mathbf{5 - 1 0} \text { yrs of } \\
\text { exposures }\end{array}$ & $\begin{array}{l}\text { More than 10 years of } \\
\text { exposure }\end{array}$ \\
\cline { 2 - 4 } & Number $(\%)$ & Number $(\%)$ & Number $(\%)$ \\
\hline$\leq 200$ & $9(3)$ & $6(8.8)$ & $9(37.5)$ \\
\hline $201-300$ & $111(37)$ & $39(57.4)$ & $15(62.5)$ \\
\hline $301-400$ & $144(48)$ & $20(29.4)$ & - \\
\hline $401-500$ & $33(11)$ & $3(4.4)$ & - \\
\hline$>500$ & $3(1)$ & - & - \\
\hline TOTAL & 300 & 68 & 24 \\
\hline
\end{tabular}

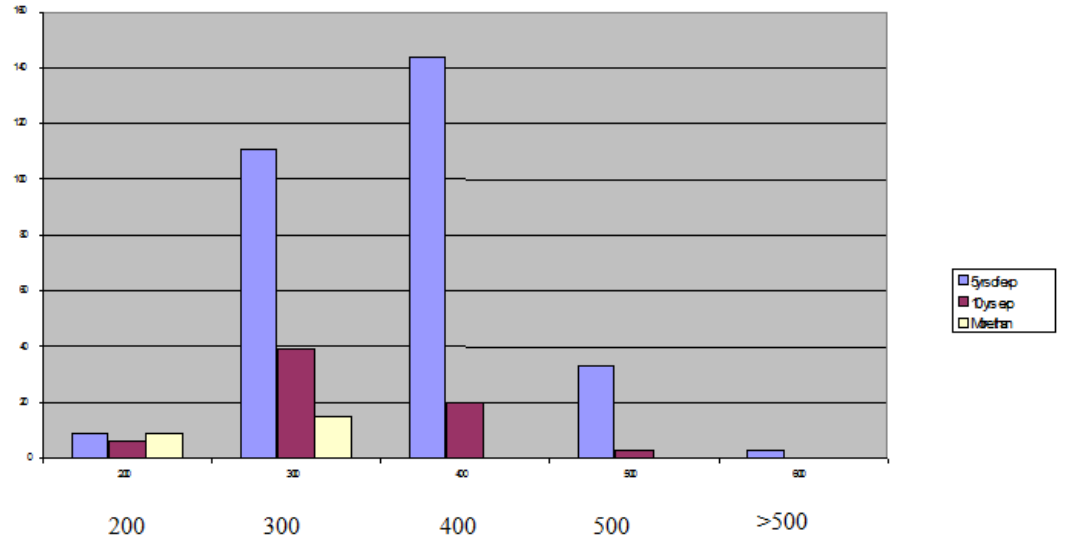

Fig. 2: Distribution Ofthe Three Categories Of Workers For Various Values Of Fev

Table 10: Fevi For Workers With Less Than 5 Years Exposure

\begin{tabular}{|l|l|l|}
\hline $\begin{array}{l}\text { FEVI } \\
(\mathbf{m l})\end{array}$ & Frequency $(\mathbf{f})$ & Percent \\
\hline$\leq 200$ & 9 & 3.0 \\
\hline $201-300$ & 111 & $37-0$ \\
\hline $301-400$ & 144 & 48.0 \\
\hline $401-500$ & 33 & 11.0 \\
\hline$>500$ & 3 & 1.0 \\
\hline TOTAL & 300 & 100 \\
\hline
\end{tabular}

Table 11: Fevi For Population Of Workers With 5-10 Years Of Exposure

\begin{tabular}{|l|l|l|}
\hline FEVI (ml) & Frequency (f) & Percent \\
\hline$\leq 200$ & 6 & 8.8 \\
\hline $201-300$ & 39 & 57.4 \\
\hline $301-400$ & 20 & 29.4 \\
\hline $401-500$ & 3 & 4.4 \\
\hline$>500$ & - & - \\
\hline TOTAL & 68 & 100 \\
\hline
\end{tabular}


Table 12:Fevi For Population Of Workers With More Than 10 Years Exposure

\begin{tabular}{|l|l|l|}
\hline FEVI $(\mathbf{m l})$ & Frequency $(\mathbf{f})$ & Percent \\
\hline$<200$ & 9 & 37.5 \\
\hline $201-300$ & 15 & 62.5 \\
\hline $301-400$ & - & - \\
\hline $401-500$ & - & - \\
\hline$>500$ & - & - \\
\hline TOTAL & 24 & 100 \\
\hline
\end{tabular}

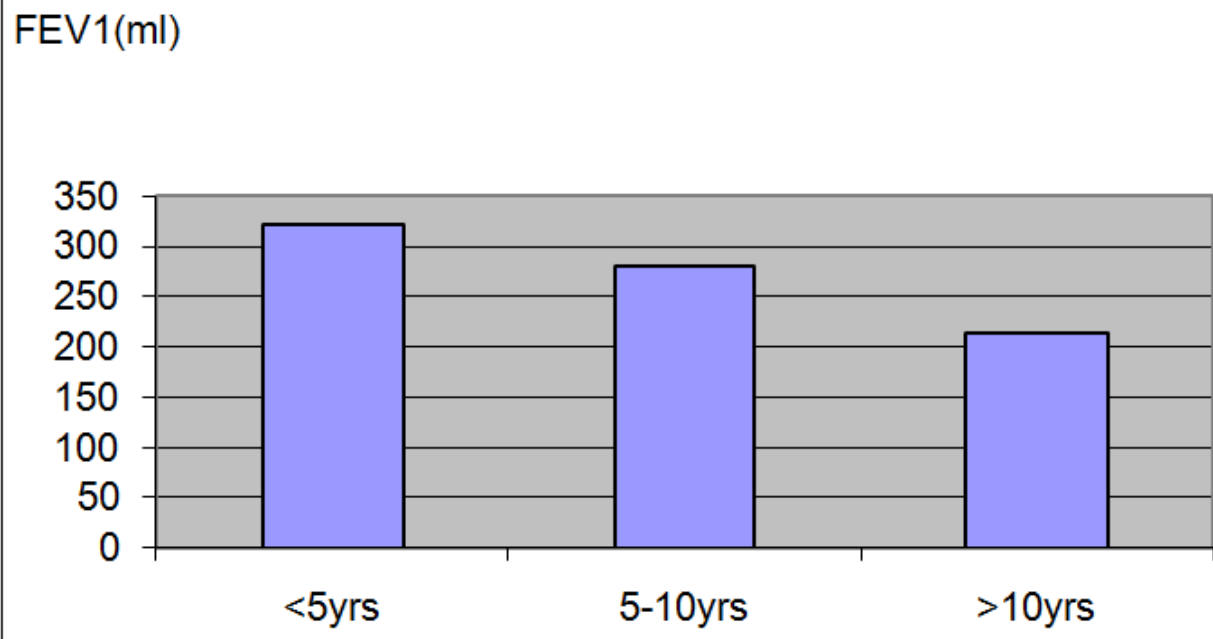

Fig. 3: Mean Fev1 For The Three Categories Of Workers

Table 13: Fevi Of Workers Who Snuff Or Smoke Tobacco

\begin{tabular}{|l|l|l|}
\hline FEVI & Frequency $(\mathbf{f})$ & Percent \\
\hline$<200$ & 12 & 8.2 \\
\hline $201-300$ & 78 & 53.4 \\
\hline $301-400$ & 45 & 30.8 \\
\hline $401-500$ & 8 & 5.5 \\
\hline$>500$ & 3 & 2.1 \\
\hline TOTAL & 146 & 100 \\
\hline
\end{tabular}

Table 14: Urinalysis Result Of The 392 Quarry Workers

\begin{tabular}{|l|l|l|}
\hline Type of test & Number of Workers & Percent \\
\hline Proteinuria & 60 & 15.3 \\
\hline Haematuria & 12 & 3.1 \\
\hline Normal Urine & 320 & 81.6 \\
\hline Total & 392 & 100 \\
\hline
\end{tabular}

